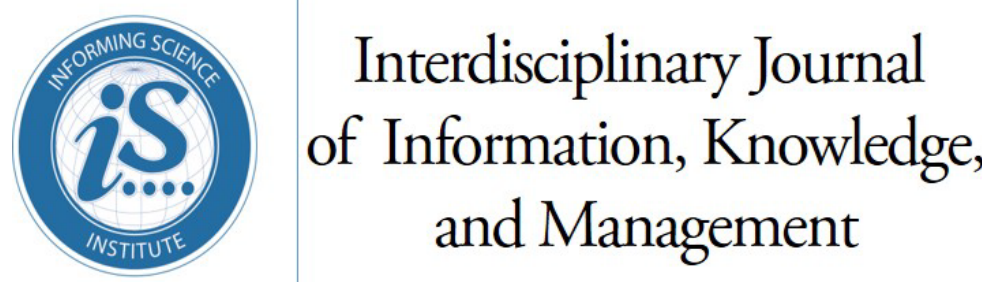

Volume 12, 2017
An Official Publication

of the Informing Science Institute

InformingScience.org

IJIKM.org

Senior Editors-in-Chief: Mike Hart, Elsje Scott, and Kevin Johnston, University of Cape Town, South Africa

Acting Editor-in-Chief: Lynn Jeffrey, Massey University, New Zealand

Associate Editor in Chief: Geoffrey Z. Liu, San Jose State University, United States

Associate Editor in Chief: June Lu, University of Houston-Victoria, United States

Managing Editor: Eli Cohen, Informing Science Institute, USA

Publisher: Elizabeth Boyd; Informing Science Institute, USA

Editors:

Jeffrey Alstete, Iona College (USA)

Tharrenos Bratitsis, University of Western Macedonia (Greece)

Harry Tomas Fulgencio, Leiden University (Netherlands)

Salah Kabanda, University of Cape Town (South Africa)

Nelson K. Y. Leung, RMIT International University (Vietnam)

Rajeev Manhas, Baba Farid University of Health Sciences (India)

Christine Nya Ling TAN, Multimedia University (Malaysia)

Maureen Tanner, University of Cape Town (South Africa)

Dale Trott, Central Queensland University (Australia)

Jon K. Webber, University of Phoenix (USA)

Ewa Ziemba, University of Economics in Katowice (Poland)

The mission of the Interdisciplinary Journal of Information, Knowledge, and Management (IJIKM) is to provide readers with the widest possible coverage of the use of information and technology to effectively create, apply, and communicate knowledge in organizations. In addition to manuscripts that center on knowledge acquisition and sharing, agent-based systems, neural networks, genetic algorithms, learning systems, and natural language processing, we welcome manuscripts on a wide range of topics relating to the organizational use and management of information and technology.

IJIKM publishes scholarly conceptual, theoretical and empirical manuscripts on the use of information technology to enhance organizational performance. Submissions to the journal should be readable and understandable by a wide audience. Manuscripts should therefore also focus on practical application or illustration of the issues covered, rather than merely providing a mathematical or technical coverage, which would be more suitable for a specialist journal.

All manuscripts are submitted and reviewed electronically. We provide our published authors with both a quality print publication and the widespread readership that comes from publishing all manuscripts online within a few weeks of acceptance. This approach ensures that published works are read and cited by the widest possible audience. 
IJIKM is an academically peer reviewed Journal. All submissions are blind refereed by three or more peers. IJIKM is published in print by subscription and its articles also appear online free of charge on the web site http://ijikm.org

IJIKM is listed in Cabell's Directory of Publishing Opportunities in Educational Technology \& Library Science, Cabell's Directory of Publishing Opportunities in Management, Directory of Open Access Journals (DOAJ), EBSCO, Index of Information System Journals, Ulrichs.

(CC BY-NC 4.0) The articles in this journal are licensed under a Creative Commons AttributionNonCommercial 4.0 International License. When you copy and redistribute this paper in full or in part, you need to provide proper attribution to it to ensure that others can later locate this work (and to ensure that others do not accuse you of plagiarism). You may (and we encourage you to) adapt, remix, transform, and build upon the material for any non-commercial purposes. This license does not permit you to use this material for commercial purposes.

ISSN Print 1555-1229, Online 1555-1237 ISBN: 978-1-68110-024-1

\footnotetext{
Published by the Informing Science Institute 131 Brookhill Ct., Santa Rosa, California USA phone: +1-707-537-2211; fax: +1-815-301-6785 http://informingscience.org
} 


\section{IJIKM Volume 12, 2017 - Table of Contents}

Understanding Internal Information Systems Security Policy Violations as Paradoxes

Kennedy Njenga

Factors Affecting Re-usage Intentions of Virtual Communities Supporting Cosmetic Products

Chien-Ta Ho, Jhong-Min Yang, and Wei-Ting Chen 17-36

ICT-Platform to Transform Car Dealerships to Regional Providers of Sustainable Mobility Services

Benjamin Wagner vom Berg, Jorge Marx Gómez, and Alexander Sandau

A Systematic Literature Review of Agile and Maturity Model Research

Vaughan Henrique and Maureen Tanner

A Cognitive Knowledge-based Framework for Social and Metacognitive Support in

Mobile Learning

Ahmed Al-Hunaiyyan, Andrew Thomas Bimba, Norisma Idris, and

Salah Al-Sharhan

Enterprise Ontology Model for Tacit Knowledge Externalization in Socio-Technical Enterprises

Shreyas Suresh Rao and Ashalatha Nayak

Data Visualization in Support of Executive Decision Making

Jeanne Moore

The Effect of Personality Traits on Sales Performance: An Empirical Investigation to Test the Five-Factor Model (FFM) in Pakistan

Abdul Waheed, Jianhua Yang, Jon Webber

The Penta Helix Model of Innovation in Oman: An HEI Perspective

Alrence Santiago Halibas, Rowena Ocier Sibayan, Rolou Lyn Rodriguez Maata 159-174

Transforming Communications in the Workplace: The Impact of UC on Perceived Productivity in a Multi-national Corporation

Joy Fluker and Meg Murray

Reasons for Poor Acceptance of Web-Based Learning using an LMS and VLE in Ghana

Isaac Asampana, Albert A. Akanferi, James Ami-Narh

Typology on Leadership toward Creativity in Virtual Work

Iris Humala

Research Foci, Methodologies, and Theories Used in Addressing E-Government Accessibility for Persons with Disabilities in Developing Countries

Millicent Agangiba, Salah Kabanda

The Utilisation of Facebook for Knowledge Sharing in Selected Local Government Councils in Delta State, Nigeria

Uzoma Heman Ononye, Rev. Fr. Anthony Igwe

An Empirical Examination of Customers' Mobile Phone Experience and Awareness of Mobile Banking Services in Mobile Banking in Saudi Arabia

Ayman N. Alkhaldi

Accounting Information Systems Effectiveness: Evidence from the Nigerian Banking Sector

Shamsudeen Ladan Shagari, Akilah Abdullah, Rafeah Mat Saat 309-335 
The Application of a Knowledge Management Framework to Automotive Original Component Manufacturers

Andre P. Calitz, Margaret Cullen 